\title{
Literature and Nationalism: Relation between Books of Travels and the Process of the Czech National Identity Formation
}

\author{
Přemysl Ovský \\ University of West Bohemia, Faculty of Philosophy and Arts, Department of Anthropology, Czech Republic
}

\begin{abstract}
This paper analyses books of travels in the context of the process of the Czech national identity formation illustrated by the book of travels of Václav Vratislav of Mitrovice. Since 1777 until today his book was published eleven times overall. It is by far the most editions among the travel works in the Czech modern history. The aim of this study is to explain the extraordinary success of this book. Therefore this work represents a contribution to the analysis of the Czech national revival and the history of Czech exotic ethnography. The methodology of this paper lies in the hermeneutic analysis of the individual editions since 1777. The particular consideration is focused on the historical background of these editions in the context of the Czech national identity formation. Determinative role for the popularity of Vratislav's masterpiece played the modern written language. During the Czech nationalism formation the style of this book helped to codify the modern Czech language. Furthermore, the first edition of the book did not reproduce Vratislav's originative text, but it was modified by the editor just for the national-revivalist purposes. The book represents an artificially modified national symbol supporting the newly formed Czech nationalism. During the additional editions, the book of travels became an ethnic symbol, which played an important role in the process of forming the Czech nation. It has been perceived as the founding stone of the Czech national feeling, which was strengthened by repeated re-editions over the next two centuries until the present day.
\end{abstract}

Keywords: book of travels; Czech ethnography; nationalism; Czech national revival; Václav Vratislav of Mitrovice 